\title{
Boys Boys Boys
}

\section{Gender, Race and the English Music Question}

\author{
TIMOTHY LAURIE \\ UNIVERSITY OF SYDNEY
}

Laurie Stras (ed.)

She's So Fine: Reflections on Whiteness, Femininity, Adolescence and Class in 1960s Music

Ashgate, Surrey, UK, 2010

ISBN 9781409400516

RRP $€ 55$ (hb)

Andy Bennett and Jon Stratton (eds)

Britpop and the English Music Tradition

Ashgate, Surrey, UK, 2010

ISBN 9780754668053

RRP $£ 50(\mathrm{hb})$

Debates over the value of canons have taken a while to reach some quarters of popular music studies. In two recent collections, Stras's She's So Fine: Reflections on Whiteness, Femininity, Adolescence and Class in 1960s Music and Bennett and Stratton's Britpop and the English Music Tradition, contributors rethink the relationships between gender, history and musical identity by examining the much- 
mythologised 'turning points' of pop and rock history-the early 1960s' British Invasion and the Britpop explosion of the 1990s, respectively-by peering into their underbellies: what happened to girl groups when the Rolling Stones hit Rolling Stone? Were Elastica a Britpop band in the same sense that Oasis were, and would they even want to be? And is there something more to Little Englandism than faux nostalgia and boys havin' a laugh?

Taken together, both collections merit close attention for the questions they ask of the well-trodden rock narratives and Mojo-fueled 'Golden Era' sentimentality. Laurie Stras's introduction to She's So Fine follows recent publications by Marion Leonard, Norma Coates, Sheila Whiteley and Jacqueline Warwick (among others) in contesting representations of girl groups and female pop stars as transient, fluffy, expendable and interchangeable, as well as music historians' own privileging of male rock artists. Stras emphasises those shared experiences of girlhood that cut across social and cultural divisions, an important point given how easily histories of American and UK pop music subsume girls within the faceless mass of the 'mainstream consumer'. The introduction also broaches wider academic considerations when linking the absence of girl groups from music histories to the relative under-theorisation of 'girlhood' in youth cultural studies. Defending girl group singing against its mostly male detractors, Stras's own chapter engages with the nuances of teen girls' vocal techniques, with case studies including Dodie Stevens, Patience and Prudence, the Bobbettes, the Chantels and the Shirelles. Stras's confidence in bringing social considerations together with the physiological constraints of actually singing girl group classics offers an invaluable resource for anyone working on gender and the voice, although the differences in the cultural contexts of music pedagogy-from gospel church singing to studios in New Yorkmerit further examination.

In keeping with Stras's emphasis on pop femininity, Robynn J. Stilwell examines child star Brenda Lee, although not before an eclectic journey through rockabilly androgeny, 'white trash', Lolita, and the post-World War II rock'n'roll aesthetic. Her focal discussion of Lee centres on the ambivalences between girlhood 'innocence'-the gifted star who knows-not-what-she-does-and the self-knowing prodigal daughter, who intimates a sexual maturity 'unfitting' for her age. By teasing out the slippages and ambiguities within this morally loaded dichotomy, Stilwell 
questions the obligation to read Lee as either one or the other of two strictly opposed, but in fact impossibly intertwined, feminine identities. The moral constraints of feminine pop performance are also foregrounded by Jacqueline Warwick, who surveys violence and the 'angry girl' trope from the Crystals' infamous 'He Hit Me (And it Felt like a Kiss)' through to Hole (who cover 'He Hit Me') and Ashlee Simpson's more contrived 'bad girl' aesthetic. Warwick's linkage of girl groups' bodily conduct to the broader contexts of gendered self-discipline frames a strong reading of Martha and the Vandellas and the Supremes, but is introduced by an offhand discussion of foot-binding in Jung Chang's Wild Swans, a huge topicwomen, class and modernity in early twentieth-century China-that distracts from the specific cultural contexts at hand. Further research in this area might be better served by a consultation of Patricia Hill Collins, Paula Giddings and Michele Wallace's respective works on public performances of African American femininity in the 1960 s. $^{1}$

Shifting to the United Kingdom for Section Two, British Girls in the Mid-60s, a stand-out piece that provides an excellent introduction to whiteness and femininity in popular culture is Annie J. Randall's 'Dusty's Hair'. The author moves seamlessly from Dusty Springfield's status as a 'mod icon' to a discussion of her racial drag as the White Queen of Soul and finally to Springfield's artistic expression as an accomplished vocalist and producer. While some sections warrant a more critical attitude towards Springfield-Dusty's remark 'I wish I'd been born coloured' is quite provocative-Randall's meticulous attention to the multiple constructions of 'Dusty' through newspapers, magazines, television shows and recordings enables a nuanced understanding of white women in the 1960s pop music industry, and illuminates Dusty's own strategies to create a distinct artistic identity within the limited 'feminine' roles afforded her. Similarly, Patricia Juliana Smith examines the popularity, decline, and subsequent comebacks of the four female stars-Sandie Shaw, Cilla Black, Lulu and Petula Clark-from the 1960s to the present day. While each artist had limited control over her recordings and career decisions-Mickie Most and Brian Epstein are, quite rightly, named among the villains-Smith argues that the long-term significance of these female stars is comparable to, and frequently eclipses, that of overly fetishised male groups like the Zombies. In her epilogue, Smith ties the enduring influence of the Brit Girls to the girl power of the 1990s, thus 
complicating the historical revisionism that imagines the Spice Girls without predecessors, or reconstructs 1960s female popstars as always-already powerless.

Introducing a less familiar female pop star, Sarah Hill's 'Mary Hopkin and the Deep Throat of Culture' draws loosely on the sexual metaphor of swallowing a 'foreign cultural product' to examine Welsh singer Mary Hopkin's English crossover record, Post Card (1969). Hill's intimate knowledge of Welsh pop music, especially regionally accented vocal inflections, allows an intriguing analysis of the differences between Hopkin's Welsh and English-language recordings. However, Hill's dichotomies between her 'essentially Welsh' protagonist and 'English culture', 'Anglophone culture', and 'foreign, Anglo-American culture' (emphases in original), as well as her figuration of cultural mixtures in terms of physical rape, risks slipping from justified assertions of Welsh sovereignty to more xenophobic articulations of cultural nationalism. Although only adjacent to her engaging musicological and lyrical analyses, Hill's clash of cultures narrative probably needs to be reconsidered in its broader historical context, especially given the historical coincidence of Hopkins' cross-over with Enoch Powell's anti-immigrationist assertion of 'local' particularisms-English, Welsh, and Scottish-against non-white cultural contamination.

In the final section Rock Chicks and Resistance at the End of the 60s, Norma Coates skewers rock journalists' canonisation of male rock stars against their female associates by focusing on representations of Marianne Faithfull and the Rolling Stones. Coates's close attention to the often contradictory constructions of the Faithfull myth-effete British artistocrat coupled with drug-addled parasitehighlights the double-edged blade of 'rock girlfriend' stardom, while avoiding any easy 'victim narrative' by following Faithfull's subsequent reinvention as a cult feminist icon. Like Patricia Juliana Smith, Coates uses her subject's recent career trajectory to complicate the constructions of women in the music business as either 'eye candy' or passive dupes. In the same vein, Susan Fast recovers Tina Turner from disparaging representations by the rock establishment, emphasising Turner's creative agency beyond the well-documented influence of Ike. Fast's use of Henry Louis Gates's concept of 'signifyin(g)' (originally used to describe repetition, irony and the double-voiced utterance within African oral traditions and African diasporic literatures) to explain Turner's cover versions is at times frustrating, given that 
black artists' recordings of songs by white composers were commonplace throughout the doo-wop era and up to Aretha Franklin's cover of 'Satisfaction' (1967) and the Miracles' 'Yesterday' (1968). Nevertheless, the closing discussion of Turner's reinvention as a 'tough girl' using white models of muscular femininity, borrowed mainly from Hollywood, persuasively brings Fast's main point home: namely, there was no space for women in 1960s rock'n'roll except through highly negotiated, potentially self-satirising borrowings from newly invented models of authentic (white) self-expression.

She's So Fine announces a strong critique of the gender norms and masculinised aesthetics of the rock press and rock historiography, while the contributors' detailed use of examples pushes the discussions beyond mere polemic. There is a risk, of course, that by recovering a girl group canon as something 'by' and 'for' girls, Stras's volume ignore those girls who like non-girl group music, or the fans of girl group recordings who did not fit into record distributors' marketing profiles. However, the overall project of revaluing women's music histories against the lazy denigrations of rock critics allows for many rewarding discussions of gender in the music industry, and foregrounds an alternative understanding of US and UK musical identities that is less visible, although not absent from, Britpop and the English Music Tradition (hereafter Britpop).

Some common critical concerns between She's So Fine and Britpop are suggested in Bennett and Stratton's succinct introduction. The editors problematise Britpop's London focus ('Eng-pop'), its convergence with the embedded conservatisms of Blair's Cool Britannia, its contrived English nostalgias, and its basic gender and race biases. To historicise such concerns around English 'traditions' and musical authenticity, David Laing's opening discussion of music hall is invaluable for a broader understanding of British pop before the 1960s and the later parochialisms of Britpop, particularly Blur. Following music hall's popularity in the late nineteenth century, through the hullabaloo of cinema and the genre's subsequent revivals and reinventions, Laing argues that selective 'recoveries' of music hall have elided its specific cultural contexts, especially its rich use of humour concomitant with the concerns of the day.

This historical overview provides the necessary context for Jon Stratton's own two contributions, 'Skiffle, Variety and Englishness' and 'Englishing Popular 
Music in the 1960s'. Drawing on the concept of cultural imperialism, Stratton questions the common depiction of English groups as malevolently appropriating African-American music, pointing to a larger economic context in which 'the English ... were the subordinate group'. (31) Establishing a distinction between American mass culture and 'Englishness', Stratton argues that the Beatles reached 'white teens' in the United States because they added melody to 'rhythmic' AfricanAmerican music. A cursory listen to the Platters, the Drifters or the Miracles seems to unsettle this argument; according to historians Nelson George and Brian Ward, the success of the British Invasion had little to do with the gap between 'English' melody and 'African-American' rhythm, and more to do with record industry structure, particularly racialised distribution channels.

To be fair, Stratton's central argument is more that the assertion of Englishness through music hall influences in recordings by the Beatles, the Kinks, Herman's Hermits and the Rolling Stones (among others) was not necessarily nostalgic, but rather foregrounded 'the most popular form of entertainment in England' (48) against American pop culture saturation. Stratton successfully refutes reductive understandings of music hall as an anachronism of the late nineteenth century, but in doing so allows music hall and British Invasion artists to stand in for 'English' sensibilities and 'English' pop music tastes. His insistence that genres like skiffle became 'indigenised' as English when performed by working-class white men certainly warrants a more careful gender analysis. Importantly, Stratton's genealogy of music hall through 1960 s pop and rock recordings does provide original historical insight, but his rationale for selecting distinctly 'English' songs and artists-Dusty Springfield and Petula Clark disappear entirely-needs to be made more transparent within the appropriate cultural and music industry contexts.

A welcome shift in perspective is introduced by the sole consideration of women in Britpop, Sheila Whiteley's 'Trainspotting: The Gendered History of Britpop'. Taking key examples Elastica, Sleeper and Echobelly, Whiteley argues that despite various techniques of gender play and critical reflexivity, female-led Britpop groups were often treated as novelties within a discourse that deified the thoughts and antics of Jarvis Cocker, Damon Albarn and others. Whiteley's astute recognition that gender considerations were in many cases imposed from without by the music press, who controlled the terms on which 'femininity' came to be understood in 
Britpop, offers new insights into familiar debates around whether Elastica and others really offered empowering images of women in rock. Whiteley's chapter is included under the History and Context heading, rather than the Britpop section (were Elastica not Britpop enough?), forcing the reader to backtrack from 1991 to 1971 for Andy Bennett's discussion of 'lost' 1970s and early 1980s pop/rock artists. Bennett locates the discourse of Little England later identified with Britpop in the much earlier polyvocal expressions of Englishness by groups like Slade, Cockney Rebel and others, artists later ignored by the 'anti-establishment' sloganeering of punk-era commentaries. Bennett does not actually offer any explanations as to why 'Englishness' became so unfashionable in the 1970s rock press, but he does provide insights into the often unexpected correspondences between the discourse of English belonging between diverse artists, genres and periods.

Politics of the parliamentary kind is foregrounded in the first chapter of the Britpop section, Rupa Huq's 'Labouring the Point? The Politics of Britpop in "New Britain"'. Huq traces the parallel rise of Britpop, 'a post-ideological soundtrack to post-political times' (100), and Tony Blair's New Labour, tied together by the retro kitsch of Cool Britannia and a collapsed separation between socialist and conservative politics, or between an indie left and a middle-of-the-road pop. The lack of comparative analysis slightly blunts Huq's modest claims: while Britpop was less 'political' than Crass, one of Huq's few historical comparisons, so were most of Crass's contemporaries. However, her closing argument that 'reclaiming' the Union Jack was part of an insidious nationalism that denied its own conservative implications reminds us that the notions of 'post-ideology' or 'post-politics' are themselves thoroughly ideological and inevitably political. Expanding the lens beyond Huq's mainly English focus, J. Mark Percival draws on a rich archive of interview material, music reviews and biographical knowledge to tease out the complexities of regionalism in reactions to Britpop, or in his more accurate monicker, 'Eng-pop', which might have been further modified to 'Lon-pop' if it did not sound so silly. Taking Travis, Mogwai, the Delgados, Super Furry Animals, the Manic Street Preachers and Stereophonics as case studies, Percival argues that positive constructions of Scottishness or Welshness were articulated against a supposedly inauthentic London-based Britpop. Throughout, one wonders how Echobelly or Elastica would have been positioned vis a vis the Welsh or Scottish 
boys: would the terms of local authenticity be different? Would the music press even make such a comparison? These are the sorts of questions that Whiteley's chapter and She's So Fine handle excellently, and could be further developed in Percival's discussion.

In one of the more musicological chapters of Britpop, Stan Hawkins links the vocal techniques of Pulp, Blur, Oasis and the Manic Street Preachers' frontmen to laddism, heterosexism and white ethnicity. The musicological claim that 'the Britpop voice adheres to a genealogy of British bands' (152) would have been better supported by comparisons with earlier British bands (everything from the Zombies to Zeppelin risks being invoked), and with Britpop groups fronted by female singers. These limitations notwithstanding, Hawkins's handling of laddism as a backlash to feminism, or at least popular representations of feminism, is extremely useful, and invites further research into the aesthetics of so-called post-feminist masculinities. Derek B. Scott offers a more strict analysis of 'The Britpop Sound', dispelling the popular myth that Oasis (and others) were mere musical imitators of the Beatles. In his discussion of modernism and postmodernism, Scott acknowledges that the concept of musical progress is part of a cultural discourse to which Oasis did not subscribe, and it remains unclear whether Scott really believes that musicologically demonstrable differences are strong indexes of originality. But given the persistent flogging of the Oasis-Beatles comparisons, perhaps it takes musicology to shut the argument down for good.

Reflecting on the Britpop aftermath and its successors, Ian Collinson's chapter 'Devopop' raises important questions about the construction of English identity and musical heritage. Collinson contrasts the Kaiser Chiefs' and Arctic Monkeys' recent re-hashings of English nostalgia with the Bloc Party's 'critical cosmopolitanism', which draws attention to the multitude of experiences still described under the rubric of Englishness. Collinson's recognition that English pop since the 1950s has always been culturally hybrid also enables him to complicate the assumption that issues of racial and ethnic difference only become relevant to understanding pop-Englishness in the 1990s. In close conversation with the themes of Collinson's chapter, Nabeel Zuberi's closing discussion challenges the insistence on locating British pop within the bounds of a national musical culture, informed by his observation that rhetoric around border protection, cultural citizenship and 
alien outsiders tends to bleed from politics to musical labelling. By following MIA's reception in the US and the traces of Arabic, Asian and African sounds in dubstep, Zuberi performs a displacement of England as the sole site through which musical pasts (or futures) are understood. In his closer readings of Dizzee Rascal, Zuberi also makes important connections between police surveillance in Britain, the construction of racial difference as culturally deviant, and the containment of nonwhite artists through a spatialisation of authenticity that, like CCTV cameras, insists that knowing where someone is equates to knowing why they do what they do, musically or otherwise.

The post-Britpop section questions many of the assumptions smuggled into the notion of an 'English music tradition', the glue that binds together both of the earlier sections. It is unfortunate that the close attention paid to the racial and gender politics of Britpop in the late 1990s is not extended to its antecedents in the Kinks or late nineteenth-century music hall, especially given the profusion of literature on non-white musics in Britain before the official sanction of multiculturalism. The chimera of the canon (the lads' one, that is) remains intact throughout key chapters in Britpop, and limits otherwise important re-evaluations of the Britpop, or Eng-pop, mythology. While She's So Fine does not explicitly foreground nation as a primary concern, it highlights the complexities of 'British pop', and its trans-Atlantic relatives, as a contested space of gendered belonging, and perhaps does more to trouble the 'English tradition' than does Britpop. Nevertheless, the latter text does ask important questions about more recent rescriptings of Britain's narratives of nation, and provides a firm starting point from which to evaluate the changed musical landscapes of what is now a post-Labour, and maybe not quite so 'Cool', Britain.

Timothy Laurie is a PhD candidate in Gender and Cultural Studies at the University of Sydney. His thesis examines the United States' music industry, drawing on critical race theory and the political economy of Deleuze and Guattari. He is currently researching the Supremes' mid-1960s covers albums. 


\section{-NOTES}

${ }^{1}$ See Patricia Hill Collins, From Black Power to Hip Hop: Racism, Nationalism, and Feminism, Temple University Press, Philadelphia, 2006; Paula Giddings, When and Where I Enter: The Impact of Black Women on Race and Sex in America, W. Morrow, New York, 1984; and Michele Wallace, Black Macho and the Myth of the Superwoman, J. Calder, London, 1979. 